\title{
Molecular identity of Stomaphis quercus (Hemiptera: Aphidoidea: Lachnidae) and description of a new species
}

\author{
ŁUKASZ DEPA ${ }^{1}$, EWA MRÓZ1 ${ }^{1}$ and KAROL SZAWARYN² \\ ${ }^{1}$ Department of Zoology, Faculty of Biology and Environmental Protection, University of Silesia, Bankowa 9, 40-007 Katowice, \\ Poland; e-mails: lukasz.depa@us.edu.pl; ewa.mroz@us.edu.pl \\ ${ }^{2}$ Museum \& Institute of Zoology, Polish Academy of Sciences, Wilcza 64, 00-679 Warsaw, Poland; e-mail: szawaryn@miiz.waw.pl
}

Key words. Hemiptera, Aphidoidea, Lachnidae, Stomaphis, COXI, COXII, molecular systematics

\begin{abstract}
The two species of the genus Stomaphis feeding on oak and birch, respectively, although morphologically similar, are considered to be separate species. However, the birch-feeding S. betulae Mamontova is considered to be a synonym of the oak and birch feeding S. quercus (L.) by some authors. The purpose of this study was to determine whether the birch feeding and oak feeding populations attributed to $S$. quercus belong to the same species. The mitochondrial cytochrome-c oxidase I (COXI) and II (COXII) were used to determine whether these two populations differ. There are no significant differences in these markers from oak and birch feeding individuals, indicating that these populations are conspecific. However, morphologically and ecologically distinct populations of Stomaphis were discovered feeding on oak. The molecular analysis confirmed that these populations are distinct, which resulted in the description of the new oak-feeding species, Stomaphis wojciechowskii Depa, sp. $\mathrm{n}$. This new species previously remained unrecognized due to its very cryptic mode of life.
\end{abstract}

\section{INTRODUCTION}

The genus Stomaphis Walker 1870 (Aphidoidea: Lachnidae) comprises over 25 species of Palaearctic distribution, associated predominately with deciduous trees but also recorded from conifers. Among them, Stomaphis quercus (Linnaeus, 1758) is the most widely distributed, recorded throughout the whole of the Western Palaearctic. Host plants are various species of Quercus and Betula (Blackman \& Eastop, 1994). However, since the description of Stomaphis betulae Mamontova, 1969, the distribution of $S$. quercus is debatable. In Mamontova's opinion, only $S$. betulae lives on birches in the Ukraine and reports of the occurrence of $S$. quercus on birches in other countries most probably refer also to $S$. betulae (Mamontova, 1969, 1972).

Mamontova's $(1969,1972)$ description and the general consensus that Stomaphis species are monophagous has resulted in many authors regarding $S$. betulae as a good species (Eastop \& Hille Ris Lambers, 1976; Czylok \& Blackman, 1991). However, some authors question its taxonomical status based on the intra-specific variation in morphological features of S. quercus (Klimaszewski \& Płachta, 1977; Klimaszewski \& Wojciechowski, 1996). The questionable status of $S$. betulae results mainly from a lack of distinctive features not only of the specimens collected from Central European populations, but also those from the type locality (Klimaszewski \& Wojciechowski, 1996). Populations feeding on oaks and on birches in Poland and the Ukraine do not clearly differ morphologically (Klimaszewski \& Wojciechowski, 1996) and the specimens described by Mamontova are the only ones attributed to another species of Stomaphis feeding on birches in Ukraine. Blackman \& Eastop (1994) also report this species as occurring only in the Ukraine.
Klimaszewski \& Wojciechowski (1996) conducted a series of biochemical analyses of the hemolymph of representatives of Polish populations, both on birches and oaks, and found no discontinuity between the oak and birch feeding populations. There is also morphological support for the thesis that $S$. quercus and $S$. betulae are synonomous.

Thus, the need arose for detailed studies of these species taxa, including extensive field research and molecular analysis of the material collected. Two mitochondrial genes, COXI and COXII, were used as molecular markers in this study.

Mitochondrial genes are widely used in studies on the molecular systematics of insects (Simon et al., 1994). As these genes are maternally inherited (Hoy, 1994), mitochondrial sequences are suitable for reconstructing phylogenetic relationships of parthenogenetic organisms like aphids (von Dohlen \& Moran, 2000). Mitochondrial COXI and COXII have been used in phylogenetic studies of aphid families, e.g., Hormaphididae (Stern 1994, 1998; Stern et al., 1997), Lachnidae (Normark, 1999, 2000) and Aphididae (von Dohlen et al., 2006). These genes appear to be very useful for clarifying phylogenetic relationships at the tribal to generic level in aphids (Normark, 2000; Stern, 1994), as it was in the case of the tribe Fordini (Zhang \& Qiao, 2007) and the genera Uroleucon Mordvilko (Moran et al., 1999), Megoura Buckton (Kim \& Lee, 2007) and Toxoptera Koch (Wang \& Qiao, 2009). The mitochondrial genes were also used to resolve problems with species identity as in the case of a few species in the genus Macrosiphum Passerini (Turčinavičiene \& Rakauskas, 2009) and the subgenus Bursaphis McVicar Baker (Rakauskas et al., 2011), or general systematic relations within the genus Aphis L. (Coeur d'acier et al., 2007). The aim of this study was to check the molecular 
TABLE 1. Localities where the material studied was collected, their voucher numbers and GenBank accession numbers of COXI and COXII.

\begin{tabular}{|c|c|c|c|c|c|c|c|}
\hline Species & $\begin{array}{l}\text { Voucher } \\
\text { number }\end{array}$ & Collection site / Province & $\begin{array}{c}\text { Collection } \\
\text { date }\end{array}$ & Host plant & $\begin{array}{l}\text { Associated ant } \\
\text { species (Lasius) }\end{array}$ & $\begin{array}{l}\text { GenBank Ac } \\
\text { COXI }\end{array}$ & $\begin{array}{c}\text { cession No. } \\
\text { COXII }\end{array}$ \\
\hline \multirow{13}{*}{$\begin{array}{l}\text { Stomaphis } \\
\text { quercus }\end{array}$} & $\mathrm{A} 2$ & $\begin{array}{c}\text { Bobrowniki } \\
50^{\circ} 22^{\prime} 39.07^{\prime \prime} \mathrm{N}, 18^{\circ} 59^{\prime} 50.49^{\prime \prime} \mathrm{E}\end{array}$ & $12 / 06 / 10$ & Betula verrucosa & L. fuliginosus & JN944537 & JQ302807 \\
\hline & A3 & $\begin{array}{l}\text { Rudy Wielkie } \\
50^{\circ} 12^{\prime} 47.99^{\prime \prime} \mathrm{N}, 18^{\circ} 27^{\prime} 26.59^{\prime \prime} \mathrm{E}\end{array}$ & $9 / 07 / 10$ & Betula verrucosa & L. fuliginosus & JN944538 & - \\
\hline & A4 & $\begin{array}{c}\text { Rudy Wielkie } \\
50^{\circ} 12^{\prime} 35.66^{\prime \prime} \mathrm{N}, 18^{\circ} 27^{\prime} 27.38^{\prime \prime} \mathrm{E}\end{array}$ & $9 / 07 / 10$ & Quercus robur & L. fuliginosus & JN944539 & - \\
\hline & A5 & $\begin{array}{c}\text { Piekary Śląskie - Szarlej } \\
50^{\circ} 22^{\prime} 14.87^{\prime \prime} \mathrm{N}, 18^{\circ} 57^{\prime} 43.32^{\prime \prime} \mathrm{E}\end{array}$ & $5 / 07 / 10$ & Betula verrucosa & L. fuliginosus & JN944540 & - \\
\hline & A6 & $\begin{array}{c}\text { Świerklaniec } \\
50^{\circ} 26^{\prime} 27.16^{\prime \prime} \mathrm{N}, 18^{\circ} 57^{\prime} 25.43^{\prime \prime} \mathrm{E}\end{array}$ & $24 / 09 / 10$ & Quercus robur & L. fuliginosus & JN944541 & - \\
\hline & A7 & $\begin{array}{c}\text { Kalinowice } \\
50^{\circ} 29^{\prime} 58.71^{\prime \prime} \mathrm{N}, 18^{\circ} 10^{\prime} 37.02^{\prime \prime} \mathrm{E}\end{array}$ & $8 / 07 / 10$ & Quercus robur & L. fuliginosus & JN944542 & - \\
\hline & $\mathrm{S} 1$ & $\begin{array}{c}\text { Międzyzdroje } \\
53^{\circ} 56^{\prime} 2.29^{\prime \prime} \mathrm{N}, 14^{\circ} 27^{\prime} 31.92^{\prime \prime} \mathrm{E}\end{array}$ & $20 / 08 / 10$ & Quercus petraea & L. fuliginosus & JN944543 & JQ302806 \\
\hline & $\mathrm{S} 4$ & $\begin{array}{c}\text { Bratkowice } \\
50^{\circ} 7^{\prime} 27.02^{\prime \prime} \mathrm{N}, 21^{\circ} 50^{\prime} 59.96^{\prime \prime} \mathrm{E}\end{array}$ & $21 / 09 / 10$ & Quercus robur & L. fuliginosus & JN944544 & - \\
\hline & S7 & $\begin{array}{c}\text { Sandomierz } \\
50^{\circ} 41^{\prime} 12.00^{\prime \prime} \mathrm{N}, 21^{\circ} 47^{\prime} 12.54^{\prime \prime} \mathrm{E}\end{array}$ & $22 / 09 / 10$ & Betula verrucosa & L. fuliginosus & JN944545 & JQ302808 \\
\hline & $\mathrm{S} 11$ & $\begin{array}{c}\text { Piekary Śląskie } \\
50^{\circ} 24^{\prime} 2.75^{\prime \prime} \mathrm{N}, 18^{\circ} 57^{\prime} 22.84^{\prime \prime} \mathrm{E}\end{array}$ & $24 / 09 / 10$ & Betula verrucosa & L. fuliginosus & JN944546 & - \\
\hline & $\mathrm{S} 13$ & $\begin{array}{c}\text { Piekary Śląskie } \\
50^{\circ} 24^{\prime} 9.36^{\prime \prime} \mathrm{N}, 18^{\circ} 56^{\prime} 35.70^{\prime \prime} \mathrm{E}\end{array}$ & $18 / 09 / 10$ & Betula verrucosa & L. fuliginosus & JN944547 & JQ302809 \\
\hline & S14 & $\begin{array}{c}\text { Piekary Śląskie } \\
50^{\circ} 24^{\prime} 9.36^{\prime \prime} \mathrm{N}, 18^{\circ} 56^{\prime} 35.70^{\prime \prime} \mathrm{E}\end{array}$ & $1 / 07 / 10$ & Quercus robur & L. fuliginosus & JN944548 & JQ302810 \\
\hline & $\mathrm{S} 25$ & $\begin{array}{c}\text { Kotulin } \\
50^{\circ} 28^{\prime} 6.83^{\prime \prime} \mathrm{N}, 18^{\circ} 26^{\prime} 7.42^{\prime \prime} \mathrm{E}\end{array}$ & $28 / 09 / 10$ & Betula verrucosa & L. fuliginosus & JN944549 & - \\
\hline \multirow{11}{*}{$\begin{array}{l}\text { Stomaphis } \\
\text { wojciechowskii }\end{array}$} & S8 & $\begin{array}{c}\text { Sieniawa Dobra } \\
50^{\circ} 11^{\prime} 24.6^{\prime \prime} \mathrm{N}, 22^{\circ} 39^{\prime} 23.9^{\prime \prime} \mathrm{E}\end{array}$ & $24 / 09 / 10$ & Quercus robur & L. brunneus & JQ302794 & - \\
\hline & S9 & $\begin{array}{c}\text { Sieniawa Dobra } \\
50^{\circ} 11^{\prime} 24.6^{\prime \prime} \mathrm{N}, 22^{\circ} 39^{\prime} 23.9^{\prime \prime} \mathrm{E}\end{array}$ & $24 / 09 / 10$ & Quercus robur & L. platythorax & JQ302795 & - \\
\hline & $\mathrm{S} 10$ & $\begin{array}{c}\text { Lubaczów } \\
50^{\circ} 7^{\prime} 9.79^{\prime \prime} \mathrm{N}, 22^{\circ} 55^{\prime} 54.05^{\prime \prime} \mathrm{E}\end{array}$ & $23 / 09 / 10$ & Quercus robur & L. umbratus & JQ302796 & - \\
\hline & S15 & $\begin{array}{c}\text { Lubaczów } \\
50^{\circ} 7^{\prime} 6.85^{\prime \prime} \mathrm{N}, 22^{\circ} 55^{\prime} 54.96^{\prime \prime} \mathrm{E}\end{array}$ & $23 / 09 / 10$ & Quercus robur & L. platythorax & JQ302797 & JQ302811 \\
\hline & S17 & $\begin{array}{c}\text { Nowa Dęba } \\
50^{\circ} 28^{\prime} 48.49^{\prime \prime} \mathrm{N}, 21^{\circ} 41^{\prime} 55.99^{\prime \prime} \mathrm{E}\end{array}$ & $22 / 09 / 10$ & Quercus robur & L. brunneus & JQ302798 & - \\
\hline & S18 & $\begin{array}{c}\text { Lubaczów } \\
50^{\circ} 7^{\prime} 8.74^{\prime \prime} \mathrm{N}, 22^{\circ} 55^{\prime} 55.04^{\prime \prime} \mathrm{E}\end{array}$ & $23 / 09 / 10$ & Quercus robur & L. brunneus & JQ302799 & - \\
\hline & S19 & $\begin{array}{c}\text { Bratkowice } \\
50^{\circ} 6^{\prime} 3.42^{\prime \prime} \mathrm{N}, 21^{\circ} 49^{\prime} 33.63^{\prime \prime} \mathrm{E}\end{array}$ & $21 / 09 / 10$ & Quercus robur & L. brunneus & JQ302800 & JQ302812 \\
\hline & S20 & $\begin{array}{c}\text { Bratkowice } \\
50^{\circ} 6^{\prime} 3.42^{\prime \prime} \mathrm{N}, 21^{\circ} 49^{\prime} 33.63^{\prime \prime} \mathrm{E}\end{array}$ & $21 / 09 / 10$ & Quercus robur & L. brunneus & JQ302801 & JQ302813 \\
\hline & $\begin{array}{c}\text { S23 } \\
\text { type series }\end{array}$ & $\begin{array}{c}\text { Piekary Śląskie } \\
50^{\circ} 24^{\prime} 11.48^{\prime \prime} \mathrm{N}, 1^{\circ} 57^{\prime} 47.87^{\prime \prime} \mathrm{E}\end{array}$ & $23 / 10 / 10$ & Quercus robur & L. brunneus & JQ302802 & JQ302814 \\
\hline & $\mathrm{S} 26$ & $\begin{array}{c}\text { Piekary Śląskie Kalwaria } \\
50^{\circ} 22^{\prime} 54.96^{\prime \prime} \mathrm{N}, 18^{\circ} 56^{\prime} 44.44^{\prime \prime} \mathrm{E}\end{array}$ & $25 / 10 / 10$ & Quercus robur & L. brunneus & JQ302803 & JQ302815 \\
\hline & $\mathrm{S} 27$ & $\begin{array}{c}\text { Świerklaniec } \\
50^{\circ} 25^{\prime} 4.76^{\prime \prime} \mathrm{N}, 18^{\circ} 57^{\prime} 30.23^{\prime \prime} \mathrm{E}\end{array}$ & $2 / 11 / 10$ & Quercus robur & L. brunneus & JQ302804 & - \\
\hline $\begin{array}{l}\text { Stomaphis } \\
\text { graffii }\end{array}$ & $\mathrm{S} 24$ & $\begin{array}{c}\text { Kalinowice } \\
50^{\circ} 28^{\prime} 6.83^{\prime \prime} \mathrm{N}, 18^{\circ} 26^{\prime} 7.42^{\prime \prime} \mathrm{E}\end{array}$ & $28 / 09 / 10$ & Acer platanoides & L. brunneus & JQ302805 & JQ812049 \\
\hline
\end{tabular}

identity of oak and birch feeding aphids of the genus Stomaphis (supposedly S. quercus and S. betulae).

\section{MATERIAL AND METHODS}

\section{Morphological analysis}

The morphological features of the material collected for molecular analyses were also studied. In the case of the speci- mens feeding on birches (12 specimens) the only morphological features studied were those diagnostic of $S$. betulae: hair length on abdominal tergites VI-VII and the presence of sclerites at the base of the abdominal hairs (Mamontova, 1972). We did not carry out a detailed morphological study of typical oak feeding specimens as this information is available for Central European populations (Klimaszewski \& Wojciechowski, 1996). Only the morphology of oak feeding specimens that were distinctly dif- 
TABLE 2. Accession numbers of GenBank aphid sequences used in this study.

\begin{tabular}{llcc}
\hline Genus & Species & COXI & COXII \\
\hline Rhopalosiphum & nymphaeae & GU457794 & EU358855 \\
Trama & rara & EU701939 & AF156221 \\
Stomaphis & longirostris & - & AF156213 \\
Stomaphis & fagi & - & AF156210 \\
Stomaphis & aesculi & - & AF156208 \\
Stomaphis & takahashi & - & AF156217 \\
Stomaphis & malloti & - & AF156214 \\
Stomaphis & aphananthae & - & AF156209 \\
Stomaphis & yanonis & - & AF156218 \\
Stomaphis & pini & - & AF156215 \\
Stomaphis & quercus & - & AF156216 \\
\hline
\end{tabular}

ferent in life history from typical $S$. quercus was studied in detail. The first author is responsible for the morphological analysis and the description of the new species.

\section{Collection of material and sampling of outgroup taxa}

Aphid samples were kept in $95-100 \%$ ethanol and stored at $4^{\circ} \mathrm{C}$. Voucher specimens were kept in $80 \%$ ethanol and deposited in the Department of Zoology, University of Silesia. Individuals used for molecular analyses were taken from the same colony as voucher specimens and were probably members of the same clone. The list of samples collected is given in Table 1.

Two other species belonging to the family Aphididae (Rhopalosiphum nymphaeae L., 1761) and Lachnidae (Trama rara Mordvilko, 1908) were chosen as outgroups. Both genes of these two aphids were available from GenBank. In addition, in order to determine the internal relationships between species in this group we analyzed all the sequences available for species of the genus Stomaphis. The complete list of taxa and sequence accession numbers is presented in Table 2 .

\section{Molecular procedures}

Total genomic DNA was isolated using DNeasy Tissue Kit (Qiagen) following the manufacturer's instructions. Prior to extraction, we removed the entire abdomen in order to avoid possible contamination from gut contents. The following mitochondrial gene fragments were used: a $635 \mathrm{bp}$ fragment of COXI and $592 \mathrm{bp}$ fragment of COXII.
Primers used for amplification are listed in Table 3. PCR conditions for each DNA fragment are given in Table 4. DNA was visualized using 1-2\% agarose gel electrophoresis with ethidium-bromide staining. PCR products were purified using a QIAquick ${ }^{\circledR}$ PCR purification kit (Qiagen) and sequenced directly using an automated sequencer (Genome Sequencer GS FLX Roche). Complete sequences were deposited in GenBank under accession numbers given in Table 1.

\section{Phylogenetic analysis}

Chromatograms, including sense and antisense, were analysed using Chromas V2.3 software (Technelysium Pty Ltd., 2004, http://www.technelysium.com.au/chromas.html). We confirmed the correctness of the sequences by checking whether they can be appropriately translated into protein using EMBOSS Transeq on-line translator. Sequences were edited using BioEdit Sequence Alignment Editor. Alignments were made for each gene using Clustal X (Thompson et al., 1997).

The best evolutionary model for each partition was selected using jModelTest (Posada, 2008) and the Bayesian Information Criterion (Table 5). Four methods were used in the phylogenetic analyses. MrBayes 3.1.2 (Huelsenbeck \& Ronquist, 2001) was used for bayesian inference (BAY), RAxML (Stamatakis et al., 2008) for Maximum Likelihood (ML) analysis, TNT (Goloboff et al., 2008) for Parsimony (PA) analysis, and MEGA version 5 software (Tamura et al., 2011) for Neighbour Joining (NJ) clustering. For each gene a separate bayesian analysis was run for 1 million generations, which were sampled at intervals of 1,000 generations, and the burn-in procedure involved $25 \%$ of the trees generated.

\section{RESULTS}

\section{Morphological analysis}

There were no morphological differences in lengths of the hairs of the specimens collected that were diagnostic of $S$. betulae. The hair lengths of the specimens examined ranged between $0.10-0.16 \mathrm{~mm}$ and did not depend on the host species. Furthermore specimens feeding on oak had the same supposed diagnostic feature of the sclerites at the base of hairs as in S. betulae (Fig. 1).

However, some samples of aphids collected from oak clearly differed from typical S. quercus (Fig. 2). They

TABLE 3. Primers used in molecular analysis.

\begin{tabular}{lllll}
\hline Region & Gene location & Primer name & Primer sequence (5'-3') & Reference \\
\hline \multirow{4}{*}{ Mitochondria } & \multirow{2}{*}{ COXII } & $2993+$ & 5'-CATTCATATTCAGAATTACC-3' & Stern, 1994 \\
& \multirow{2}{*}{ COXI } & A3772 & 5'-GAGACCATTACTTGCTTTCAGTCATCT-3' & Normark, 1996 \\
& & LCO1490 & 5'-GGTCAACAAATCATAAAGATATTGG-3' & Folmer et al., 1994 \\
& & HCO2198 & 5'-TAAACTTCAGGGTGACCAAAAAATCA-3' & Folmer et al., 1994 \\
\hline
\end{tabular}

TABLE 4. Conditions for PCR reactions.

\begin{tabular}{|c|c|c|c|c|c|}
\hline & & \multicolumn{2}{|c|}{ COXI } & \multicolumn{2}{|c|}{ COXII } \\
\hline \multicolumn{2}{|c|}{ Initial denaturation } & \multicolumn{2}{|c|}{$94^{\circ} \mathrm{C}(60 \mathrm{~s})$} & \multicolumn{2}{|c|}{$95^{\circ} \mathrm{C}(300 \mathrm{~s})$} \\
\hline \multirow{3}{*}{$1^{\text {st }}$ step } & Denaturation & $94^{\circ} \mathrm{C}(30 \mathrm{~s})$ & & $95^{\circ} \mathrm{C}(60 \mathrm{~s})$ & \\
\hline & Annealing & $47^{\circ} \mathrm{C}(45 \mathrm{~s})$ & 35 cycles & $58^{\circ} \mathrm{C}(60 \mathrm{~s})$ & 6 cycles \\
\hline & Elongation & $72^{\circ} \mathrm{C}(60 \mathrm{~s})$ & & $72^{\circ} \mathrm{C}(60 \mathrm{~s})$ & \\
\hline \multirow{3}{*}{$2^{\text {nd }}$ step } & Denaturation & & & $95^{\circ} \mathrm{C}(60 \mathrm{~s})$ & \\
\hline & Annealing & & & $55^{\circ} \mathrm{C}(60 \mathrm{~s})$ & 27 cycles \\
\hline & Elongation & & & $72^{\circ} \mathrm{C}(60 \mathrm{~s})$ & \\
\hline \multicolumn{2}{|c|}{ Termination } & $72^{\circ} \mathrm{C}(180 \mathrm{~s})$ & & $72^{\circ} \mathrm{C}(300 \mathrm{~s})$ & \\
\hline
\end{tabular}


TABLE 5. Evolutionary model parameters selected using jModelTest and the Bayesian Information Criterion for each gene.

\begin{tabular}{lcccccccc}
\hline Gene & Substitution model & $\mathrm{R}(\mathrm{a})[\mathrm{AC}]$ & $\mathrm{R}(\mathrm{b})[\mathrm{AG}]$ & $\mathrm{R}(\mathrm{c})[\mathrm{AT}]$ & $\mathrm{R}(\mathrm{d})[\mathrm{CG}]$ & $\mathrm{R}(\mathrm{e})[\mathrm{CT}]$ & $\mathrm{R}(\mathrm{f})[\mathrm{GT}]$ & Parameter \\
\hline COXI & TIM1 + I & 1.0000 & 5.1759 & 10.2981 & 10.2981 & 62.2763 & 1.0000 & $\mathrm{p}$-inv $=0.6890$ \\
COXII & TIM2 + G & 9.7579 & 8.5197 & 9.7579 & 1.0000 & 164.2197 & 1.0000 & gamma shape $=0.1830$ \\
\hline
\end{tabular}

were always hidden deeply in bark crevices, covered by soil and attended by ants other than Lasius fuliginosus (Latreille, 1798). Alive they were paler, slightly powdered with wax and attended mainly by L. brunneus (Latreille, 1798). Morphological analysis revealed they differed slightly from typical $S$. quercus and this difference was supported by molecular analyses.

\section{Molecular analysis}

The bayesian analysis of the COXI and COXII markers revealed that there is no difference between individuals from colonies feeding on oak and birch (Figs 3 and 4). The same tree topologies were obtained using all the other phylogenetic analyses (ML, PA and NJ - not shown). All specimens from colonies feeding on these two plant genera are grouped in one well supported clade on trees obtained using sequences from both genes. Bayesian posterior probabilities for both COXI and COXII data were 1.00. There was no correlation with the host plant species. The sequences of the two markers from all the specimens studied were almost identical. There were only a few single nucleotide substitutions between the specimens analysed. There was also no correlation between the sequences and the geographical distribution of the material studied.

However, specimens originally identified as $S$. quercus from oak that differed morphologically from the typical form were in a separate well supported clade on trees based on both COXI and COXII genes (bayesian posterior probabilities of 0.83 and 1.00 , respectively) (Figs 3 and 4). Although our results showed a very close relationship between clades of typical and non-typical forms of $S$. quercus, they were distinct and supported by the morphological analysis. Thus, the morphological, molecular and also ecological differences of the material collected indi- cate that these aphids belong to a new and previously unrecognized species closely related to $S$. quercus.

\section{Systematics}

\section{S. wojciechowskii Depa, sp. n.}

Figs $2 b, 5,6$.

\section{Diagnosis}

The following features of this species differ from those of $S$. quercus:

1. The ratio of antennal length to body length is lower than 0.37, while in S. quercus it is more than 0.37;

2. The ratio of hind tarsus II (HTII) to hind tarsus I (HTI) is less than 2.85 (average: 2.71), while in $S$. quercus it is more than 2.85 (average: 2.95 );

3. The ratio of hind tarsus II (HTII) to middle tarsus II (MTII) is less than 1.31 (average: 1.28), while in $S$. quercus it is more than 1.31 (average: 1.33 );

4. In life it is of pale colour and slightly powdered with wax, with an obvious row of darker spinal plates (Figs $2 \mathrm{~b}, 6 \mathrm{a}$ ), while $S$. quercus is dark green to dark brown, shiny and lacks clearly visible spinal sclerites (Fig. 2a).

\section{Description}

Apterous viviparous female. Body elliptical, light fuscous to light brownish, dull, slightly powdered with wax (Fig. 2b); whole body, including antennae and legs, densely covered with short pubescence.

Head short, about $1.21 \mathrm{~mm}( \pm 0.05)$ wide across eyes, sclerotized; compound eyes with a triommatidium; antennae 6-segmented, pale, about $0.32-0.37$ of body length, segment VI longer than $\mathrm{V}$, antennal segment II about $1.59( \pm 0.09)$ times longer than wide; apical hairs on antennal segment VI without nodulose bases; processus terminalis about $0.045 \mathrm{~mm}( \pm 0.004)$ long, about 0.104
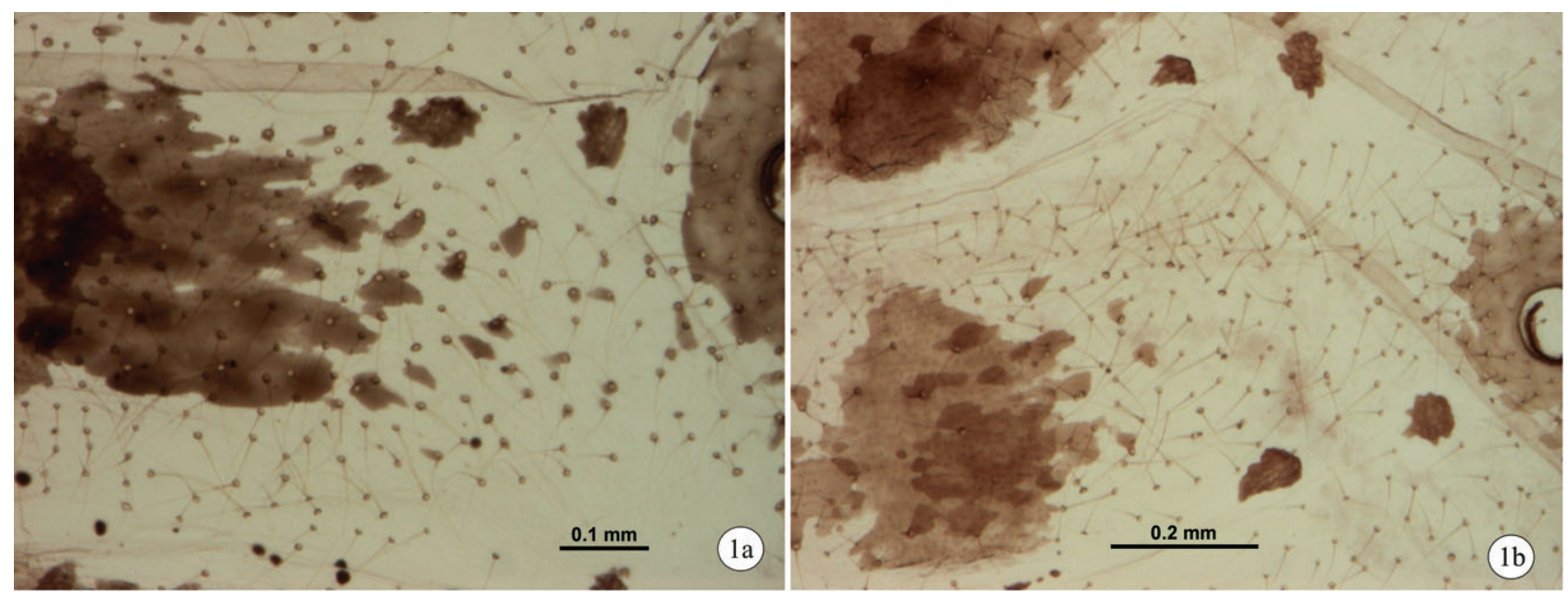

Fig. 1. Photographs of the sclerites at the bases of the hairs on the abdominal segment VI of slide-mounted apterous viviparous females of $S$. quercus from oak (a) and birch (b). 

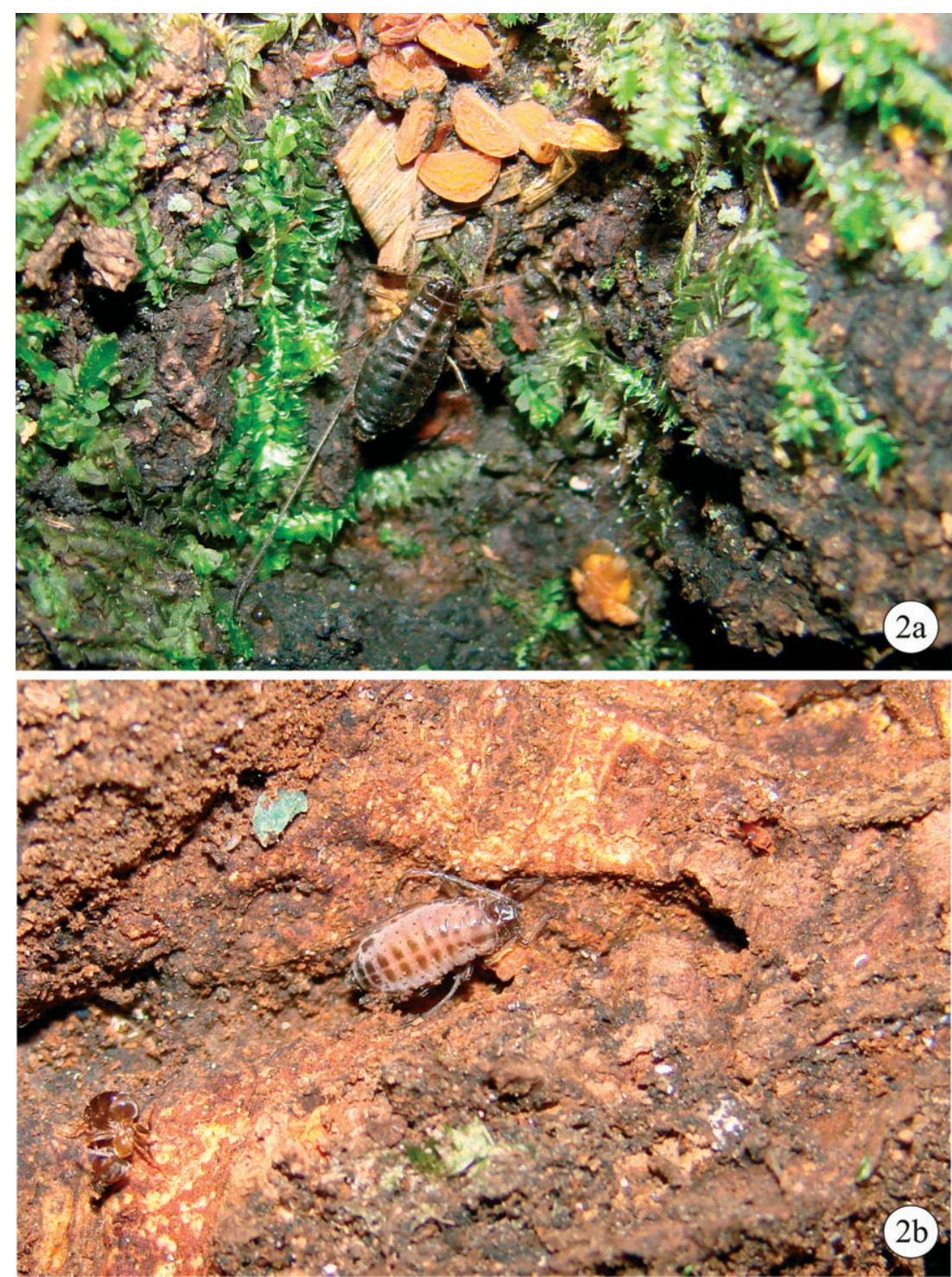

Fig. 2. Apterous viviparous female of $S$. quercus (a) and S. wojciechowskii (b).

$( \pm 0.009)$ of the basal part of antennal segment VI. Rostrum very long, about twice as long as body; rostral segment II provided with many sclerites around hair-bases. III rostral segment about $0.83 \mathrm{~mm}( \pm 0.02)$ long.

Pronotum sclerotized, mesonotum and metanotum with marginal and a pair of spinal sclerites. Coxae and trochanters dark; antennae, femora and tibiae pale, except for knees, which are slightly darker. Mean length of hind leg $4.13 \mathrm{~mm}( \pm 0.17)$, including hind femur $1.29 \mathrm{~mm}$ $( \pm 0.06)$ and hind tibia $1.99 \mathrm{~mm}( \pm 0.07)$. Hind tarsus slightly longer than middle tarsus and with longer, outstanding hairs.

Body with clearly visible row of rather small, paired spinal sclerotic plates along its whole length, regularly divided into smaller sclerites, especially on abdominal tergites IV-VI. Ventral part of abdomen with median longitudinal row of six sclerotized plates, with fine microsculpture; sixth fused with subgenital plate and thus less visible. Intersegmental muscle insertions dark. Siphunculi on sclerotic plates, subdivided into more scle- rotized cone around the siphunculus and less sclerotized part extending towards head, always divided into smaller sclerites and without well defined border; length ca. 0.59 $\mathrm{mm}( \pm 0.09)$ and width ca. $0.41 \mathrm{~mm}( \pm 0.06)$. Other measurements are given in Table 6.

Oviparous female. Very similar to the apterous viviparous female, except for the subgenital plate, which is smaller and less sclerotized with brighter groove in the middle. Also spinal sclerotic plates are always divided into many small sclerites. The measurements are given in Table 6

Male. Body small, light-green, shiny, weakly sclerotized. Abdomen provided with darker cross bars of weak sclerotization, covered with numerous, erect hairs (Fig. $5 b)$. Only genital appendices darker and more sclerotized. Measurements (based on one specimen): Body length: $2.34 \mathrm{~mm}$, length of antennal segments: I $-0.15 \mathrm{~mm}$, II $0.13 \mathrm{~mm}$, III $-0.37 \mathrm{~mm}, \mathrm{IV}-0.19 \mathrm{~mm}, \mathrm{~V}-0.24 \mathrm{~mm}$, VI $-0.31 \mathrm{~mm}$. Length of segment II of hind tarsus: $0.28 \mathrm{~mm}$. 


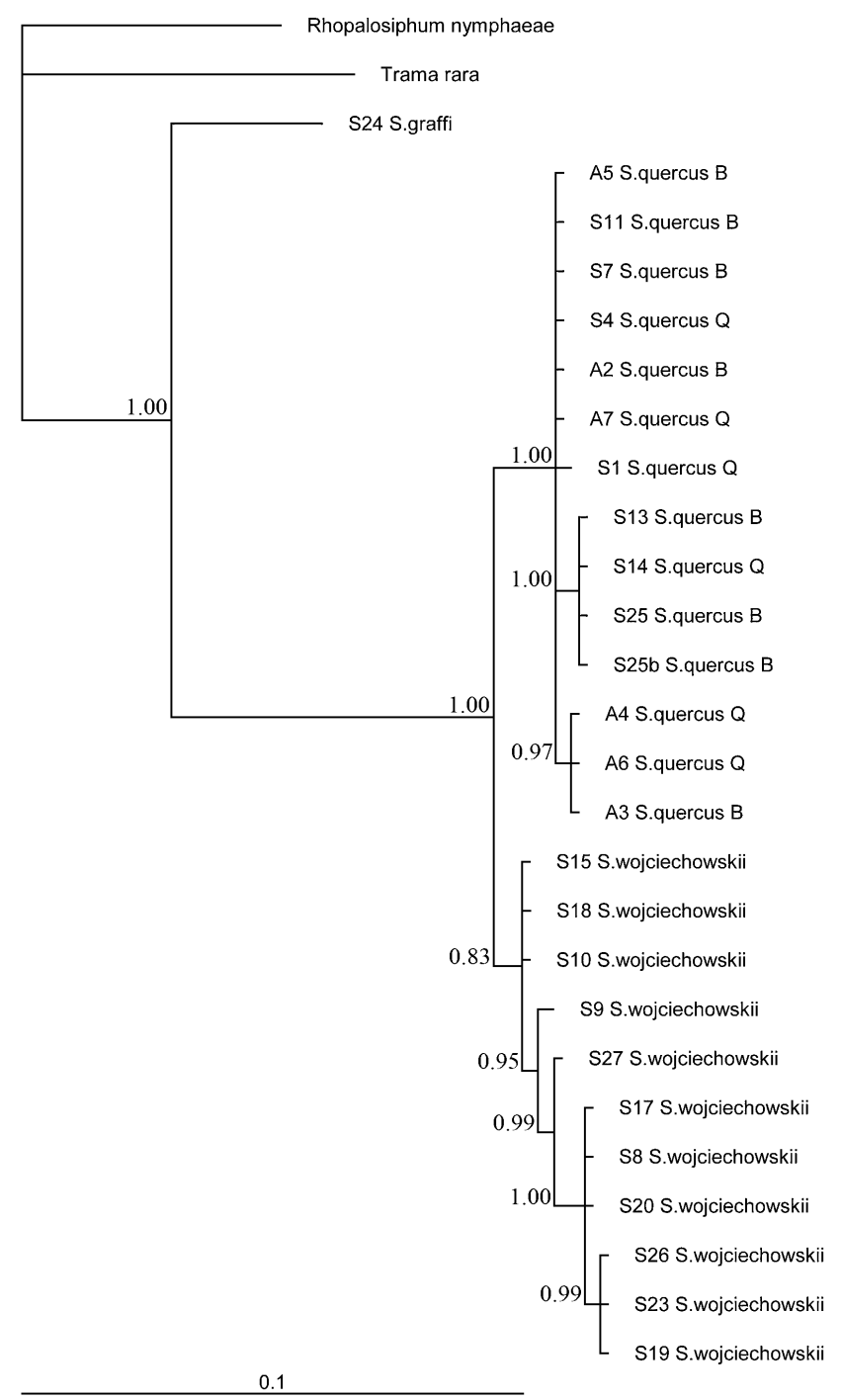

Fig. 3. Results of Bayesian analysis of COXI sequences and majority-rule consensus of post-burnin trees; posterior probabilities left of nodes; B - S. quercus collected on Betula, Q $-S$. quercus collected on Quercus.

Type material. Holotype: Apterous viviparous female (Fig. 5a), 31.x.2010. Poland, Piekary Ślaskie, "Dioblina" forest, leg. Ł. Depa. Quercus robur, slide no. 1/2A, labelled: holotype.

Measurements of the holotype (mm): Body 6.65; hind leg 4.05 (including femur 1.26 , tibia 1.97 , tarsus I 0.125 , tarsus II 0.33 ); antenna 2.15 , antennal segments: I -0.21 , II -0.17 , III $0.59, \mathrm{IV}-0.34, \mathrm{~V}-0.37, \mathrm{VI}-0.47$; ultimate rostral segment 0.68; number of rhinaria: VI $-1, \mathrm{~V}-1, \mathrm{IV}-4$, III -5 and 1 .

Paratypes (collected from the same tree and colony as the holotype): Apterous viviparous females: 31.x.2010, Poland, Piekary Śląskie, "Dioblina" forest, leg. Ł. Depa, Q. robur, slide no. 2/2A; 23.x.2010, Poland, Piekary Ślaskie, "Dioblina" forest, leg. Ł. Depa, Q. robur, L. brunneus, slide no. 2/3; 23.x.2010, same data, slide no. 3/3. Oviparous female: 23.x.2010, Poland, Piekary Śląskie, "Dioblina" forest, leg. Ł. Depa, Q. robur, L. brunneus, slide no. 1/3.

The geographical coordinates of the type locality: $50^{\circ} 24^{\prime} 11.47^{\prime \prime} \mathrm{N}, 18^{\circ} 57^{\prime} 47.87^{\prime \prime} \mathrm{E}$.

The holotype and paratypes are deposited in the collection of the Zoology Department of the University of Silesia.

Other material studied. Male, 23.ix.2010, Poland, Lubaczów, trunk base, under moss, leg. Ł. Depa, Q. robur, L. umbra-

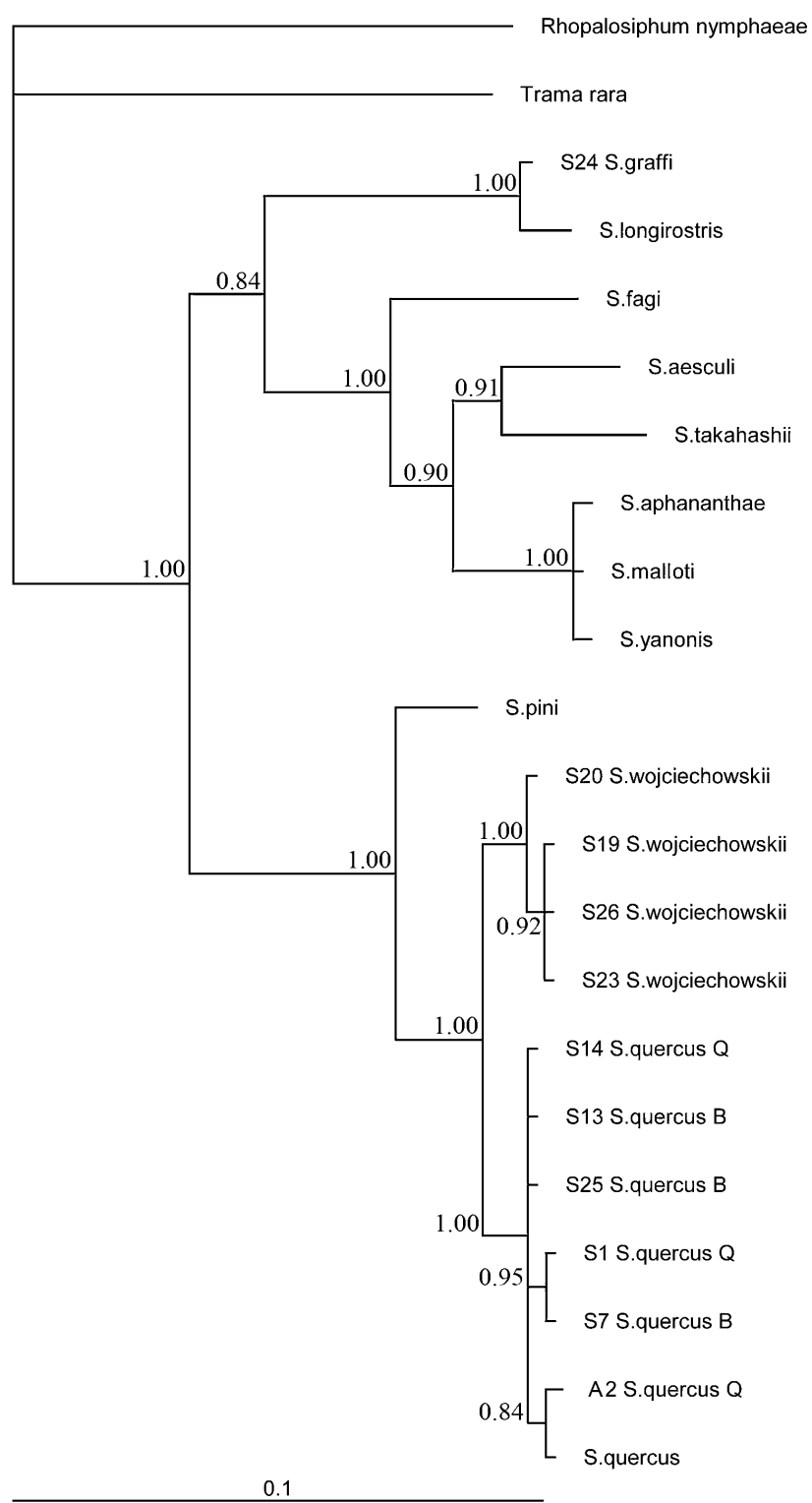

Fig. 4. Results of Bayesian analysis of COXII sequences and majority-rule consensus of post-burnin trees; posterior probabilities left of nodes; B - S. quercus collected on Betula, Q - S. quercus collected on Quercus.

tus, slide no. 2/3A. Viviparous females: 24.ix.2010, Poland, Sieniawa, leg. Ł. Depa, Q. robur, 2 ex.; 21.ix.2010, Poland, Bratkowice-Dąbry, leg. Ł. Depa, Q. robur, 2 ex.; 23.ix.2010, Poland, Lubaczów, leg. Ł. Depa, Q. robur, 1 ex. Oviparous females: 21.ix.2010, Poland, Bratkowice-Dąbry, leg. Ł. Depa, Q. robur, 1 ex.; 23.ix.2010, Poland, Lubaczów, leg. Ł. Depa, $Q$. robur, 2 ex.; 23.ix.2010, Poland, Sieniawa, leg. Ł. Depa, $Q$. robur, 1 ex.

Etymology. The species was named to honour Prof. Dr. Wacław Wojciechowski, the head of the Zoology Department of the University of Silesia and leading Polish aphid taxonomist.

Distribution. Currently it is only recorded from open deciduous and mixed forests in the Sandomierska Lowlands, northern edge of Podkarpacie, southern Roztocze and Silesian Uplands. These regions are in southern Poland, at altitudes between $100-300 \mathrm{~m}$ a.s.1.

Biology and habitat. This species feeds on basal part of the trunks of oaks, at ground level or up to ca $1.8 \mathrm{~m}$ 
TABLE 6. Measurements of female specimens of $S$. wojciechowskii sp. n. (n - number of specimens studied, URS - ultimate rostral segment, HTII - second segment of hind tarsus).

\begin{tabular}{|c|c|c|c|c|c|c|c|c|c|c|c|c|c|c|c|c|c|}
\hline & & \multicolumn{5}{|c|}{ Number of rhinaria } & \multicolumn{6}{|c|}{ Antennal segments length } & \multirow{2}{*}{$\begin{array}{l}\text { Antenna } \\
\text { length }\end{array}$} & \multirow{2}{*}{ URS } & \multirow{2}{*}{$\begin{array}{l}\text { Hind } \\
\text { leg }\end{array}$} & \multirow{2}{*}{ HTII } & \multirow{2}{*}{$\begin{array}{l}\text { Body } \\
\text { length }\end{array}$} \\
\hline & & VI & V & IV & III & Total & VI & $\mathrm{V}$ & IV & III & II & I & & & & & \\
\hline \multirow{3}{*}{$\begin{array}{l}\text { Apterous } \\
\text { viviparous } \\
\text { females } \\
\mathrm{n}=9\end{array}$} & mean & 1 & 1 & 3.89 & 0.56 & 6.44 & 0.48 & 0.34 & 0.34 & 0.61 & 0.17 & 0.23 & 2.16 & 0.67 & 4.21 & 0.42 & 6.46 \\
\hline & $\max$ & 1 & 1 & 5 & 2 & 9 & 0.50 & 0.37 & 0.36 & 0.65 & 0.18 & 0.24 & 2.27 & 0.71 & 4.37 & 0.47 & 6.81 \\
\hline & $\min$ & 1 & 1 & 3 & 0 & 5 & 0.45 & 0.32 & 0.31 & 0.59 & 0.15 & 0.22 & 2.10 & 0.64 & 4.03 & 0.40 & 6.13 \\
\hline \multirow{3}{*}{$\begin{array}{l}\text { Oviparous } \\
\text { females } \\
n=5\end{array}$} & mean & 1 & 1 & 3.80 & 0 & 5.80 & 0.47 & 0.34 & 0.32 & 0.59 & 0.16 & 0.23 & 2.12 & 0.71 & 3.98 & 0.41 & 6.20 \\
\hline & $\max$ & 1 & 1 & 5 & 0 & 7 & 0.49 & 0.36 & 0.35 & 0.62 & 0.17 & 0.24 & 2.18 & 0.72 & 4.24 & 0.45 & 6.71 \\
\hline & $\min$ & 1 & 1 & 3 & 0 & 5 & 0.46 & 0.32 & 0.31 & 0.54 & 0.15 & 0.22 & 2.05 & 0.69 & 3.84 & 0.38 & 5.74 \\
\hline
\end{tabular}

above the ground, in chambers constructed within bark crevices and covered by soil by ants, and often completely overgrown by moss. In many cases, especially on young oaks, it was found under the bark, in galleries made by ants in the corky tissue of the bark, about 0.4-1.8 $\mathrm{m}$ above ground level. The aphids are so well hidden within the bark that it is often necessary to use a knife to remove large pieces of bark in order to uncover the ant chambers with aphids (Fig. 6c), which are usually on the side of the trunk exposed to the sun. It is always attended by Lasius ants, especially L. brunneus (12 observations), but also L. platythorax (2) and L. umbratus (1). L. fuliginosus does not attend this aphid even at sites where this ant is present. During the observation period (22 September - 2 November 2010) apterous viviparous females were observed as well as oviparous females copulating with males. From the end of October to early November, approximately five eggs per oviparous female were deposited within the ant chamber in the bark (Fig. $6 b)$. Thus, it is probable that this species is holocyclic and monoecious on Quercus.

\section{Key to apterous viviparous females of European species of Stomaphis}

(partly after Czylok \& Blackman, 1991 and Petrovič, 1998)

1 Antennal segment VI longer than or equal to V . . . . . . 2

- Antennal segment VI shorter than V . ............. 3

2 All abdominal tergites have a large pair of pigmented spinal sclerotic plates, sometimes broken into small sclerites . . . . 4

- Anterior abdominal tergites without pigmented spinal plates. ............................. 6

3 Second segment of hind tarsus at least 1.4 times longer than second segment of mesothoracic tarsus. . . . . . . . . 7

- Second segment of hind tarsus at most 1.35 times longer than second segment of mesothoracic tarsus. ....... 8

4 Length of antennal segment II equal or subequal to its width; spinal sclerites never divided into smaller sclerites; on Juglans spp... . . . . . S. mordvilkoi Hille Ris Lambers

- Antennal segment II at least 1.4 times its width; spinal sclerites IV-VI at least partly divided into small sclerites; on Quercus or Betula ....................... 5

5 Antenna at most 0.37 length of body; HTII/HTI less than 2.85; HTII/MTII less than 1.31; in life fuscous, dull, slightly powdered with wax. ...... S. wojciechowskii Depa, sp. n.

- Antenna more than 0.37 length of body; HTII/HTI more than 2.85; HTII/MTII more than 1.31; in life dark, shiny ... . .............................. quercus (L.)

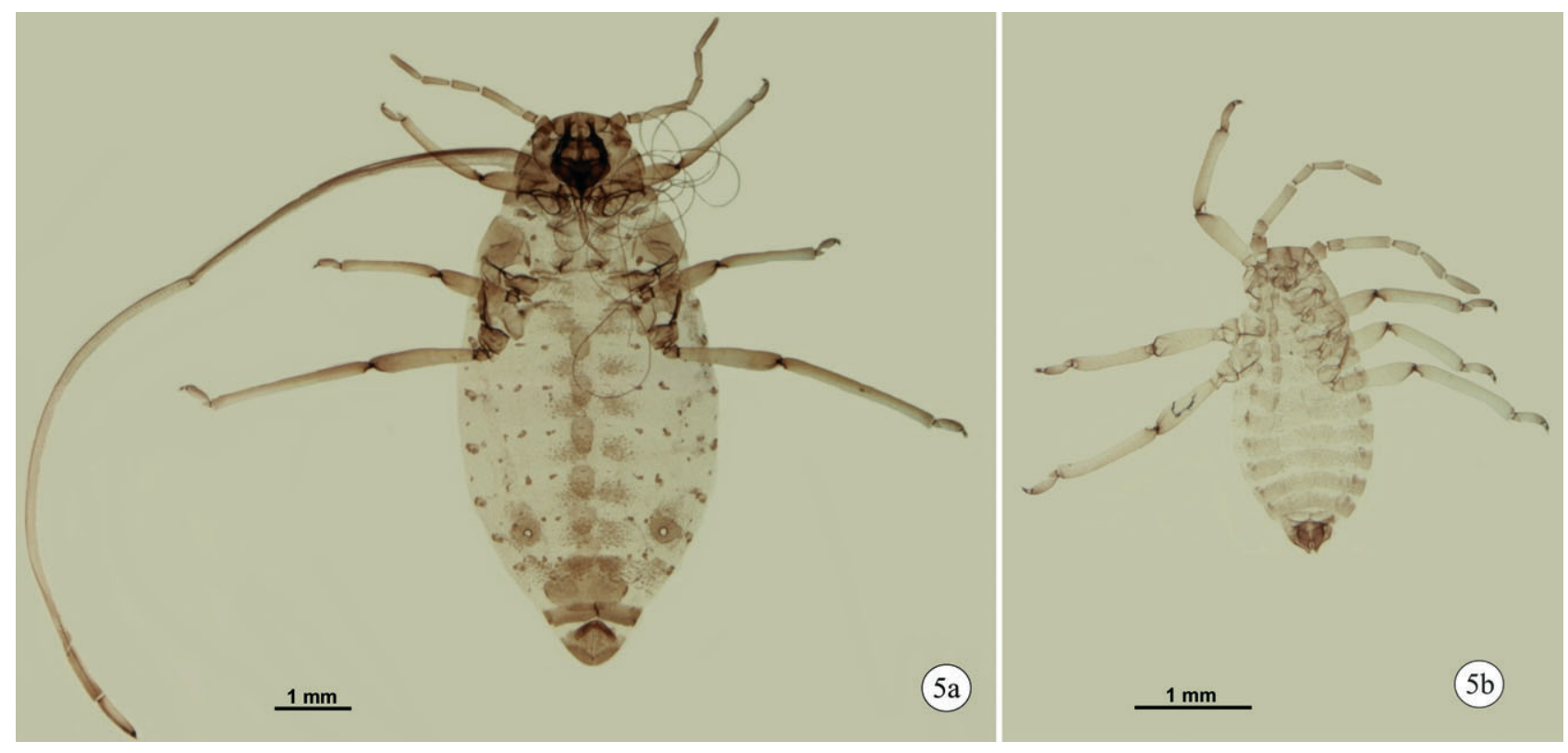

Fig. 5. Photographs of slide-mounted apterous viviparous female holotype (a) and male (b) of S. wojciechowskii sp. n. 

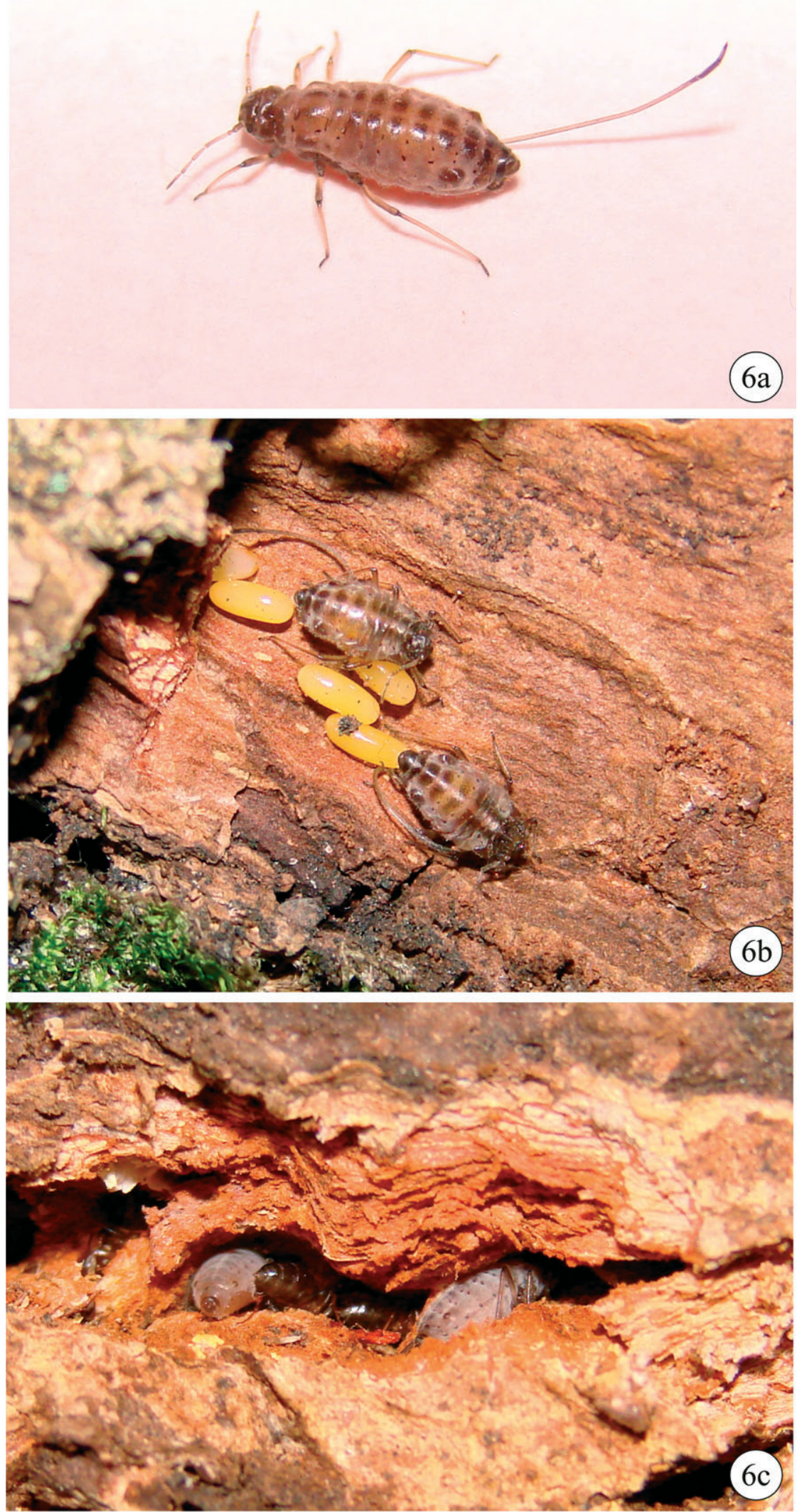

Fig. 6. Photographs of an apterous viviparous female of S. wojciechowskii sp. n. (a), oviparous females with eggs (b) and apterous females feeding in a crevice deep in bark and attended by ants (c) (a section of bark was removed to uncover the aphids, which are normally well hidden). 
6 Second segment of hind tarsus at most 1.45 times longer than second segment of mesothoracic tarsus; antennal segment VI distinctly longer than segment V; on roots of Betula spp.................. radicicola Hille Ris Lambers

- Second segment of hind tarsus more than 1.55 times longer than second segment of mesothoracic tarsus; antennal segment VI approximately as long as segment V; on trunks of Quercus petraea .... S. bratislavensis Czylok \& Blackman

7 Labrum covered with numerous hairs along its entire length; living under bark on trunks of Salix and Populus spp. . . . . . $\ldots \ldots \ldots \ldots \ldots \ldots \ldots \ldots \ldots$. longirostris $(\mathrm{F}$. - Labrum covered with dense hairs only on basal part; living in crevices in the bark of Juglans regia . . . . . . . . . . ......................... S. juglandis Petrović

8 Length of processus terminalis about equal to or less than greatest diameter of primary rhinarium; living on trunks of Cupressus spp................... S. cupressi Pintera

- Processus terminalis longer than greatest diameter of primary rhinarium; on different plants . . . . . . . . . . . 9

9 Ultimate rostral segment short, about as long as its basal width; living on trunks of Acer campestre, A. tataricum and A. platanoides..............S. graffii Cholodkovsky

- Ultimate rostral segment longer than its basal width; living in bark crevices of Acer pseudoplatanus.

..................... S. acerina Mamontova

\section{DISCUSSION}

\section{S. quercus vs $S$. betulae}

The analyses presented are based on earlier morphological and biochemical studies carried out with the objective of elucidating the taxonomic status of $S$. betulae (Klimaszewski \& Wojciechowski, 1996). The molecular data presented supports the authors' thesis that $S$. betulae is a synonym of $S$. quercus, and confirms that the specimens studied do not differ morphologically. The presence of sclerites at the bases of the hair of specimens collected from oaks makes Mamontova's (1972) diagnostic feature of $S$. betulae unreliable. Also the lengths of the hairs of the specimens studied fall within the range recorded for $S$. quercus.

$S$. quercus is not strictly associated with a single host as it feeds on both Quercus spp. and Betula spp. (Lorenz \& Scheurer, 1998). Thus, the description of a new species on the basis of it being associated with a different host plant, which is only weakly supported by morphological features, would be unreliable in this case. In one of the cases studied, the two specimens collected from different tree species (samples S13 and S14) were visited by ants from the same nest. So the individuals from the same aphid colony may feed both on oak and birch and may be transported between trees by ants (Lorenz \& Scheurer, 1998). When we take into consideration ecological features (Rakauskas, 1998) there is no difference between $S$. betulae and $S$. quercus in terms of host plant, feeding location, life cycle, attendant ant and biome - locus typicus of $S$. betulae (Zhytomyr) is in north-western Ukraine). The molecular analysis helped to resolve the taxonomic problem in this case as in the previous case of the Macrosiphum knautiae and M. silvaticum complex (Turčinavičienë \& Rakauskas, 2009), which also proved to be a single species.
At least in one species, Stomaphis japonica Takahashi (Takada, 2008), there is a possibility of host alternation between two oak species (Quercus serrata and Q. acutissima). This species has both brachypterous alate morphs and alatae with normally developed wings, which are able to disperse by flying. However, in this study of $S$. quercus (and $S$. betulae) no long- or short-winged individuals were recorded and therefore it is most unlikely that it host alternates between Quercus and Betula.

In conclusion it must be stated that there is no morphological, biochemical, ecological or molecular data supporting the separation of birch-feeding Stomaphis colonies from $S$. quercus L.

\section{S. quercus vs $S$. wojciechowskii Depa, sp. n.}

Blackman \& Eastop (1994) are of the opinion that $S$. quercus may contain several species. In fact, the differences in the nucleotide sequences of the mitochondrial markers studied are small but consistently correlated with morphological and ecological variation of the newly described species (Žurovcová et al., 2010). One of the morphological features of $S$. wojciechowskii sp. n., the spinal sclerites divided into many small sclerites, is mentioned by Szelegiewicz (1978) as a feature of S. quercus. It seems that Szelegiewicz did not regard it as a characteristic feature of a separate species and did not notice that it differed in its ecology. S. wojciechowskii is easily distinguishable morphologically in life by its body colour and waxy covering, from $S$. quercus. Surprisingly, the ecological segregation is not the host plant (as typical for aphids: Szelegiewicz, 1978), but the feeding location (on the trunk surface, in bark crevices vs ant chambers under the bark or within the bark). Furthermore, it is worth noticing that the ecological segregation of both species is closely associated with the mode of life of their ant host. $S$. quercus, which is always associated with $L$. fuliginosus, lives freely on the surface of the trunk or in bark crevices because its ant host forages above ground and on the surface of tree trunks. S. wojciechowskii on the other hand is often well hidden under the bark as its main host ant species L. brunneus nests in the interior of old trees and as a result its workers are rarely seen and underrecorded due to their cryptic life style (Collingwood, 1979). In conclusion, the molecular analysis using mitochondrial sequences proved the existence of these species.

ACKNOWLEDGEMENTS. We wish to thank J. Gorczyca (University of Silesia) for his comments on taxonomical issues and W. Tomaszewska (Museum and Institut of Zoology Polish Academy of Science), P. Węgierek (University of Silesia) and R. Milanowski (University of Warsaw) for their valuable comments on earlier version of the manuscript. We also thank two anonymous reviewers who significantly improved the quality of the manuscript.

\section{REFERENCES}

BLACKMAN R.L. \& EAstop V.F. 1994: Aphids on the World's Trees. An Identification and Information Guide. CAB International, London, $987 \mathrm{pp}$. 
Coeur D'acier A., Jousselin E., Martin J.-F. \& Rasplus J.-Y. 2007: Phylogeny of the genus Aphis Linnaeus, 1758 (Homoptera: Aphididae) inferred from mitochondrial DNA sequences. Mol. Phylogenet. Evol. 42: 598-611.

Collingwood C.A. 1979: The Formicidae (Hymenoptera) of Fennoscandia and Denmark. Fauna Entomologica Scandinavica 8. Scandinavian Science Press, Klampenborg, 174 pp.

Czylok A. \& Blackman R.L. 1991: A new species of Stomaphis Walker (Homoptera: Aphididae) from Czechoslovakia. J. Nat. Hist. 25: 665-669.

Eastop V.F. \& Hille Ris Lambers D. 1976: Survey of the World's Aphids. Dr. W. Junk, The Hague, 573 pp.

Folmer O., Black M., Hoeh W., Lutz R. \& Vrijenhoek R. 1994: DNA primers for amplification of mitochondrial cytochrome c oxidase subunit I from diverse metazoan invertebrates. Mol. Mar. Biol. Biotechnol. 3: 294-299.

Goloboff P.A., Farris J.S. \& Nixon K.C. 2008: TNT, a free program for phylogenetic analysis. Cladistics 24: 774-786.

Hoy M.A. 1994: Insect molecular systematics and evolution. In Hoy M.A. (ed.): Insect Molecular Genetics. Academic Press, New York, San Diego, pp. 337-379.

HuelsenBeCK J.P. \& Ronquist F. 2001: MrBayes: Bayesian inference of phylogenetic trees. Bioinformatics 17: 754-755.

Kim H. \& LeE S. 2008: Molecular systematics of the genus Megoura (Hemiptera: Aphididae) using mitochondrial and nuclear DNA sequences. Mol. Cells 25: 510-522.

Klimaszewski S.M. \& PŁachta J. 1977: Mszyce (Homoptera, Aphidodea) okolic Kalisza Pomorskiego [Plant lice (Homoptera, Aphidodea) from Kalisz Pomorski region.] Acta Biol. 3: 94-113 [in Polish, English abstr.].

Klimaszewski S.M. \& Wojciechowski W. 1996: Infrasubspecific variation of Stomaphis quercus (L.) (Homoptera, Aphidinea, Lachnidae) in the light of morphological and biochemical analyses. Acta Biol. Siles. 29(46): 15-23.

LORENZ H. \& SCHEURER S. 1998: Biology and generation-order of Stomaphis quercus (Lachnidae) living on Betula pendula near Berlin, Germany. In Nieto Nafría J.M. \& Dixon A.F.G. (eds): Aphids in Natural and Managed Ecosystems. Universidad de León, pp. 243-250.

Mamontova V.A. 1969: New species Stomaphis betulae sp. n. from birch-tree. Zbirn. Prats Zool. Muz. (Kiyv) 33: 68-70 [in Ukrainian].

Mamontova V.A. 1972: Popielici - Lachnidi. Fauna Ukrainy 20(7). Naukova Dumka, Kiev, 228 pp. [in Ukrainian].

Moran N.A., Kaplan M.E., Gelsey M.J., Murphy T.G. \& Scholes E.A. 1999: Phylogenetics and evolution of the aphid genus Uroleucon based on mitochondrial and nuclear DNA sequences. Syst. Entomol. 24: 85-93.

Normark B.B. 1996: Phylogeny and evolution of parthenogenetic weevils of the Aramigus tessellatus species complex (Coleoptera: Curculionidae: Naupactini): Evidence from mitochondrial DNA sequences. Evolution 50: 734-745.

NoRmarK B.B. 1999: Evolution in a putatively ancient asexual aphid lineage: Recombination and rapid karyotype change. Evolution 53: 1458-1469.

Normark B.B. 2000: Molecular systematics and evolution of the aphid family Lachnidae. Mol. Phylogenet. Evol. 14: 131-140.

Petrović O. 1998: A new species of Stomaphis Walker (Aphididae) from Serbia. In Nieto Nafria J.M. \& Dixon A.F.G. (eds.): Aphids in natural and managed ecosystems. Universidad de León, pp. 423-429.

Posada D. 2008: jModelTest: Phylogenetic Model Averaging. Mol. Biol. Evol. 25: 1253-1256.

RAKAUSKAS R. 1998: What is the (aphid) species? In Nieto Nafría J.M. \& Dixon A.F.G. (eds): Aphids in Natural and Managed Ecosystems. Universidad de León, pp. 451-455.
RaKauskas R., TurČInAVIČIEnÉ J. \& BaŠILOVA J. 2011: How many species are there in the subgenus Bursaphis (Hemiptera: Sternorrhyncha: Aphididae)? CO-I evidence. Eur. J. Entomol. 108: 469-479.

Simon C., Frati F., Beckenbach A., Crespi B., Liu H. \& Flook P. 1994: Evolution, weighting, and phylogenetic utility of mitochondrial gene-sequences and a compilation of conserved polymerase chain-reaction primers. Ann. Entomol. Soc. Am. 87: $651-701$.

Stamatakis A., Hoover P. \& Rougemont J. 2008: A rapid bootstrap algorithm for the RAxML web-servers. Syst. Biol. 75: 758-771.

STERN D.L. 1994: A phylogenetic analysis of soldier evolution in the aphid family Hormaphididae. Proc. R. Soc. Lond. (B, Biol. Sci.) 256: 203-209.

Stern D.L. 1998: Phylogeny of the tribe Cerataphidini (Homoptera) and the evolution of the horned soldier aphids. Evolution 52: 155-165.

Stern D.L., Aoki S. \& Kurosu U. 1997: Determining aphid taxonomic affinities and life cycles with molecular data: a case study of the tribe Cerataphidini (Hormaphididae: Aphidoidea: Hemiptera). Syst. Entomol. 22: 81-96.

SzeLEGIEwicz H. 1978: Mszyce - Aphidoidea, wstęp i Lachnidae. Klucze do oznaczania owadów Polski 17(5a). [Aphids Aphidoidea, Introduction and Lachnidae. Keys to Identification of Polish Insects.] PWN (State Scientific Publishers), Warszawa, 107 pp. [in Polish].

TAKADA H. 2008: Life cycles of three Stomaphis species (Homoptera: Aphididae) observed in Kyoto, Japan: possible host alternation of S. japonica. Entomol. Sci. 11: 341-348.

Tamura K., Peterson D., Peterson N., Stecher G., Nei M. \& KUMAR S. 2011: MEGA5: Molecular evolutionary genetics analysis using maximum likelihood, evolutionary distance, and maximum parsimony methods. Mol. Biol. Evol. 28: 2731-2739.

Thompson J.D., Gibson T.J., Plewniak F., Jeanmougin F. \& Higgins D.G. 1997: The ClustalX windows interface: flexible strategies for multiple sequence alignment aided by quality analysis tools. Nucl. Acids Res. 24: 4876-4882.

TURČINAVIČIENĖ J. \& RAKAUSKAS R. 2009: Macrosiphum on Knautia in Central Europe - molecular data support the synonymy of $\mathrm{M}$. silvaticum and M. knautiae (Hemiptera: Aphididae). Redia 92: 105-109.

von Dohlen C.D. \& Moran N.A. 2000: Molecular data support a rapid radiation of aphids in the Cretaceous and multiple origins of host alternation. Biol. J. Linn. Soc. 71: 689-717.

von Dohlen C.D., Rowe C.A. \& HeIE O.E. 2006: A test of morphological hypotheses for tribal and subtribal relationships of Aphidinae (Insecta: Hemiptera: Aphididae) using DNA sequences. Mol. Phylogenet. Evol. 38: 316-329.

WANG J. \& QIAO G. 2009: DNA barcoding of genus Toxoptera Koch (Hemiptera: Aphididae): Identification and molecular phylogeny inferred from mitochondrial COI sequences. Insect Sci. 16: 475-484.

Zhang H.C. \& QIAO G.X. 2007: Molecular phylogeny of Fordini (Hemiptera: Aphididae: Pemphiginae) inferred from nuclear gene EF-1a and mitochondrial gene COI. Bull. Entomol. Res. 97: $379-386$.

Žurovcová M., Havelka J., Starý P., Věchtová P., ChundeLOVÁ D., JAROŠOVÁ A. \& KuČEROVÁ L. 2010: "DNA barcoding" is of limited value for identifying adelgids (Hemiptera: Adelgidae) but supports traditional morphological taxonomy. Eur. J. Entomol. 107: 147-156.

Received November 10, 2011; revised and accepted February 3, 2012 